\title{
PENERAPAN ALGORITMA APRIORI UNTUK MENCARI POLA PENJUALAN PRODUK DANA PADA PT BANK RAKYAT INDONESIA (PERSERO) TBK KANCA JAKARTA PASAR MINGGU
}

\author{
Sutrisno \\ Program Studi Sistem Informasi, STMIK Nusa Mandiri Jakarta, \\ Jl. Damai No.8, Warung Jati Barat (Margasatwa), Jakarta Selatan, Indonesia, \\ E-mail: Sutrisno.trys@yahoo.com
}

\begin{abstract}
Various funding products which are offered by a bank sometimes make the clients tend to change their choices into other products from different banks. We need to make specific strategy so that we can dominate the market of this funding product. There will be selling reduction in this product if the used strategy is not appropriate. A company can use Data Mining process in order to reach the maximum profit of the fund's selling products. One of the processes is by using priory algorithm. The association rules can be found by using this priory algorithm. Then, the rules can be used as a fund selling pattern towards the clients. The purpose of priory algorithm is to find the frequent item sets that are run in a group of data. Priory analysis defined as a process of finding all the priory rules which is qualified to support and to confidence.
\end{abstract}

Keywords: association rule, confidence, priory algorithm, selling, support

\section{PENDAHULUAN}

Persaingan ragam produk perbankan yang ditawarkan dari berbagai pihak perbankan menjadikan nasabah seringkali berpindah dari satu produk perbankan ke produk perbankan lain sehingga perlu dilakukan suatu upaya dan strategi memenangkan pasar khususnya penjualan produk dana. jika strategi yang di gunakan tidak tepat maka penjualan produk dana PT Bank Rakyat Indonesia (Persero) Tbk Kanca Jakarta Pasar Minggu akan menurun dari segi penjualan. Dengan strategi yang bagus sebuah produk akan terjual dengan cepat agar penjualan dapat meningkat, sehingga tercapai laba maksimum sebagaimana menjadi tujuan perusahaan.

Pemanfaatan data penjualan produk dana PT Bank Rakyat Indonesia (Persero) Tbk Kanca Jakarta Pasar Minggu yang hanya berfungsi sebagai arsip. Padahal, data tersebut dapat dimanfaatkan dan diolah menjadi informasi yang berguna untuk peningkatan penjualan produk dana maupun inovasi produk. Menurut (Husin dan 
Mulyaningsih, 2015) Data yang tersimpan dan sudah tidak digunakan lagi dengan jumlah data yang dikumpulkan dan disimpan dalam basis data berukuran besar, dibutuhkan sebuah metode atau teknik yang dapat merubah tumpukan data tersebut menjadi sebuah informasi yang berharga yang bermanfaat untuk pengambilan keputusan bisnis dengan menggunakan perhitungan data dengan algoritma apriori.

\section{METODE PENELITIAN}

Metode Pengumpulan data yang dilakukan oleh penulis adalah: Pertama, Observasi: melakukan pengamatan secara langsung tentang pencatatan data transaksi penjualan dan pemasaran produk dana di bagian teller, customer service, dan funding officer. Kedua. Wawancara: Dalam tahap ini penulis bertanya langsung kepada rizky hidayat sebagai funding officer dan mengajukan beberapa pertanyaan mengenai proses pencatatan penjualan produk dana. ketiga, Studi Pustaka, metode ini dilakukan dengan mempelajari teori-teori melalui buku, artikel, jurnal dan bahan lain yang mendukung yang berhubungan dengan algoritma apriori pada metode association rule.

\section{Data Mining}

Data mining adalah proses yang menggunakan teknik statistik, matematika, kecerdasan buatan, dan machine learning untuk mengekstraksi dan mengidentifikasi informasi yang bermanfaat dan pengetahuan yang terkait dari berbagai database besar (Nursikuwagus \& Hartono, 2016). Data mining juga merupakan serangkaian proses untuk menggali nilai tambah berupa informasi yang selama ini tidak diketahui secara manual dari suatu basis data dengan melakukan penggalian pola-pola dari data dengan tujuan untuk memanipulasi data menjadi informasi yang lebih berharga, yang diperoleh dengan cara mengekstraksi dan mengenali pola yang penting atau menarik dari data yang terdapat dalam basis data. Semakin bertambah jumlah data macam data maka bertambah juga tantangan untuk mengolahnya. Dalam hal ini Data Mining mempunyai peranan besar dalam mengolah dan mengekstrak data. Hal terpenting dalam teknik Data Mining adalah aturan untuk menemukan pola frekuensi tinggi antar himpunan itemset yang disebut fungsi Association Rule (Aturan Asosiasi). 


\section{Konsep Data Mining}

Data mining sangat diperlukan terutama dalam mengelola data yang sangat besar untuk memudahkan aktifitas recording suatu transaksi dan untuk proses data warehousing agar dapat memberikan informasi yang akurat bagi pengguna data mining. Alasan utama data mining sangat dibutuhkan dalam industri informasi karena tersedianya data dalam jumlah yang besar dan semakin besarnya kebutuhan untuk mengubah data tersebut menjadi informasi dan pengetahuan yang berguna karena sesuai fokus bidang ilmu ini yaitu melakukan kegiatan mengekstraksi atau menambang pengetahuan dari data yang berukuran atau berjumlah besar.

\section{Association Rule}

Analisis asosiasi atau association rule mining adalah teknik data mining untuk menemukan aturan asosiasi antara suatu kombinasi item. Interestingness measure yang dapat digunakan dalam data mining adalah :

a. Support, adalah suatu ukuran yang menunjukkan seberapa besar tingkat dominasi suatu item atau itemsetdari keseluruhan transaksi.

b. Confidence, adalah suatu ukuran yang menunjukkan hubungan antar dua item secara conditional (berdasarkan suatukondisi tertentu).

Rumus untuk menghitung nilai support dari dua item tersebut adalah sebagai berikut:

$\operatorname{Support}(\mathrm{A})=\frac{\text { Jumlah Transaksi Mengandung }(\mathrm{A})}{\text { Total Transaksi }}$

Sedangkan nilai support dari 2 item diperoleh dari rumus berikut:

$$
\text { Support }(A \cap B)=\frac{\text { Jumlah Transaksi Mengandung A dan B }}{\text { Total Transaksi }}
$$

$(\mathrm{A} \cap \mathrm{B})=$ Jumlah transaksi yang memuat $\mathrm{A}$ dan $\mathrm{B}$ 
Pembentukan aturan asosiatif Setelah semua pola frekuensi tinggi ditemukan, barulah dicari aturan assosiatif yang memenuhi syarat minimum untuk confidence dengan menghitung confidence aturan assosiatif A B Nilai confidence dari aturan A B diperoleh dari rumus berikut:

Confidance $=\mathrm{P}(A \mid B)=\frac{\text { Jumlah Transaksi Mengandung A dan B }}{\text { Jumlah Transaksi Mengandung A }}$

$\mathrm{P} \quad=$ Total jumlah transaksi

\section{Algoritma Apriori}

Salah satu algoritma yang sering digunakan untuk pencarian aturan asosiasi adalah Apriori (Gunawan, dkk, 2016). Ide utama pada algoritma apriori adalah : pertama, mencari frequent itemset (himpunan item-item yang memenuhi minimum support.) dari basis data transaksi. Kedua, menghilangkan itemset dengan frekuensi yang rendah berdasarkan level minimum support yang telah ditentukan sebelumnya. Selanjutnya membangun aturan asosiasi dari itemset yang memenuhi nilai minimum confidence dalam basis data.

\section{Tanagra}

Tanagra merupakan perangkat lunak bebas untuk tujuan akademik dan penelitian. Penelitian ini melibatkan beberapa metode pada data mining dimulai dari analisis eksplorasi data, pembelajaran statistik, pembelajaran mesin hingga basis data.

\section{TAHAPAN PENELITIAN}

Metodologi penelitian yang berisi tahap-tahap penelitian yang sistematis pada penelitian ini dapat dilihat pada bagan gambar 1 . 


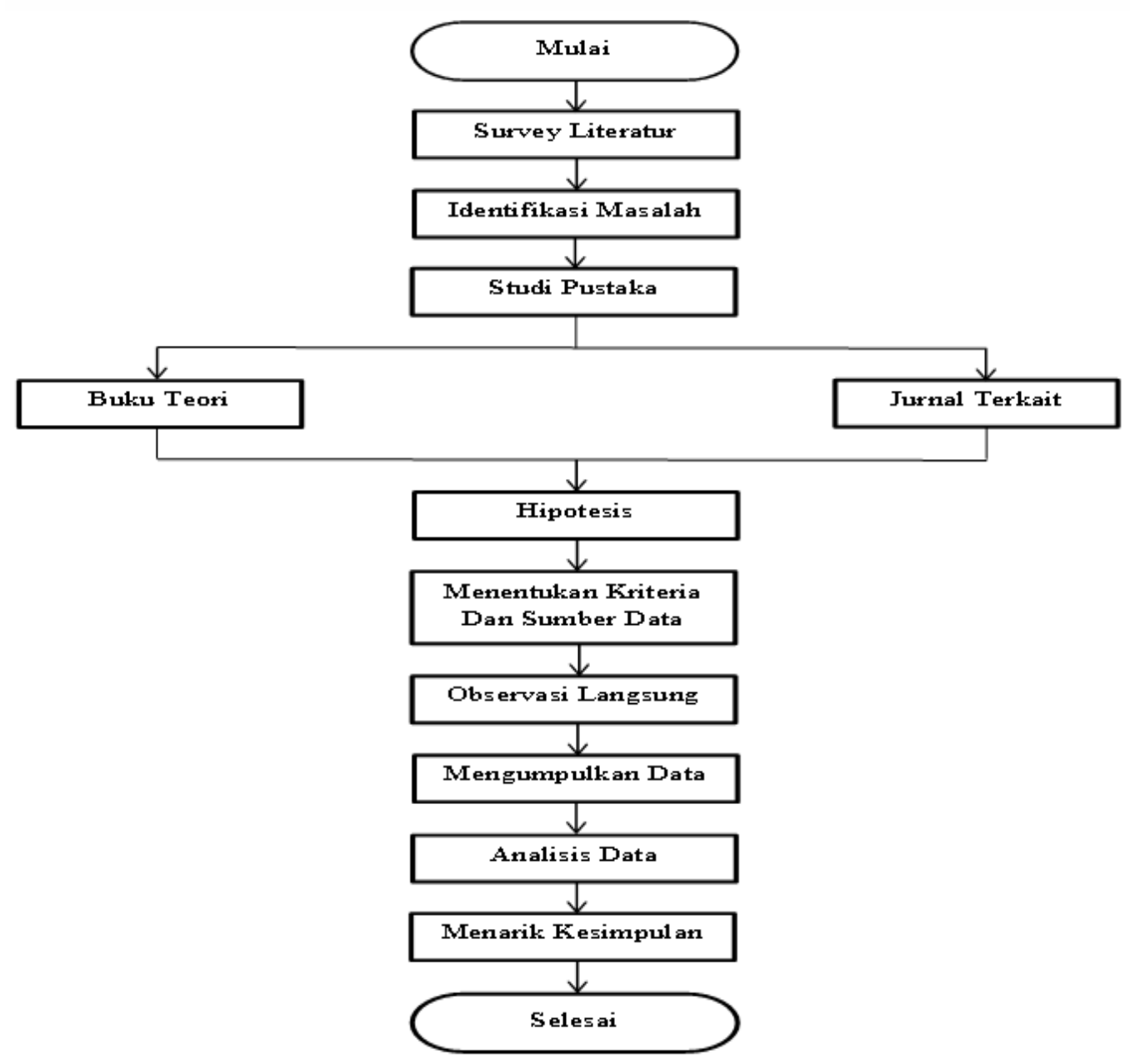

Gambar 1. Tahapan Penelitian

\section{HASIL DAN PEMBAHASAN}

untuk menemukan suatu strategi yang dapat meningkatkan penjualan dan pemasaran produk yang dijual, salah satunya adalah dengan pemanfaatan data penjualan produk dana. Data tidak hanya berfungsi sebagai arsip bagi PT Bank Rakyat Indonesia (Persero)Tbk Kanca Jakarta Pasar Minggu, data tersebut dapat dimanfaatkan dan diolah menjadi informasi yang berguna untuk peningkatan penjualan dan promosi produk dana.

\section{Daftar Type Produk Dana}

Berikut ini adalah daftar Tipe Produk Dana PT Bank Rakyat Indonesia (Persero)Tbk Kanca Jakarta Pasar Minggu, dapat dilihat pada Tabel 1. 
Tabel 1. Daftar Produk Dana

\begin{tabular}{|c|l|}
\hline No. & \multicolumn{1}{|c|}{ Nama Produk } \\
\hline 1 & Giro \\
\hline 2 & Deposito \\
\hline 3 & Britama \\
\hline 4 & Britama Bisnis \\
\hline 5 & Britama Rencana \\
\hline 6 & Britama Junio \\
\hline 7 & Britama Muda \\
\hline 8 & Simpedes \\
\hline 9 & Simpedes Impian \\
\hline 10 & BRI Prioritas \\
\hline 11 & DPLK \\
\hline 12 & Davestera \\
\hline 13 & Dasetera \\
\hline
\end{tabular}

Sumber : Hasil Penelitian (2018)

\section{Pola Transaksi Penjualan Produk Dana}

pola transaksi dengan menganalisis 3 tipe Produk Dana yang paling banyak terjadi setiap bulannya selama 1 tahun, dapat dilihat pada Tabel 2 .

Tabel 2. Pola Transaksi Penjualan Produk Dana

\begin{tabular}{|c|l|}
\hline Bulan & \multicolumn{1}{|c|}{ Item Set } \\
\hline 1 & Simpedes, Britama, Britama Junio \\
\hline 2 & Britama, Simpedes, Britama Rencana \\
\hline 3 & Britama Muda, Britama Junio, Britama Rencana \\
\hline 4 & Britama, Britama Rencana, Britama Muda \\
\hline 5 & Britama, Simpedes, Britama Junio \\
\hline 6 & Britama Rencana, Britama Junio, Britama \\
\hline 7 & Britama Junio, Simpedes, Britama Muda \\
\hline 8 & Britama, Simpedes, Britama Rencana \\
\hline 9 & Britama, Britama Rencana, Britama Junio \\
\hline 10 & Simpedes, Britama Muda, Britama \\
\hline 11 & Britama Rencana, Simpedes, Britama Muda \\
\hline 12 & Simpedes, Britama Muda,Britama Junio \\
\hline
\end{tabular}




\section{Pembuatan Format Tabular}

Format Tabular data transaksi bulanan, bila dibentuk akan tampak seperti Tabel 3. berikut ini :

Tabel 3. Tabel Format Tabular Data Transaksi

\begin{tabular}{|c|c|c|c|c|c|}
\hline Bulan & Britama & $\begin{array}{c}\text { Britama } \\
\text { Rencana }\end{array}$ & $\begin{array}{c}\text { Britama } \\
\text { Junio }\end{array}$ & $\begin{array}{c}\text { Britama } \\
\text { Muda }\end{array}$ & Simpedes \\
\hline $\mathbf{1}$ & $\mathbf{1}$ & $\mathbf{0}$ & $\mathbf{1}$ & $\mathbf{0}$ & $\mathbf{1}$ \\
\hline $\mathbf{2}$ & $\mathbf{1}$ & $\mathbf{1}$ & $\mathbf{0}$ & $\mathbf{0}$ & $\mathbf{1}$ \\
\hline $\mathbf{3}$ & $\mathbf{0}$ & $\mathbf{1}$ & $\mathbf{1}$ & $\mathbf{1}$ & $\mathbf{0}$ \\
\hline $\mathbf{4}$ & $\mathbf{1}$ & $\mathbf{1}$ & $\mathbf{0}$ & $\mathbf{1}$ & $\mathbf{0}$ \\
\hline $\mathbf{5}$ & $\mathbf{1}$ & $\mathbf{0}$ & $\mathbf{1}$ & $\mathbf{0}$ & $\mathbf{1}$ \\
\hline $\mathbf{6}$ & $\mathbf{1}$ & $\mathbf{1}$ & $\mathbf{1}$ & $\mathbf{0}$ & $\mathbf{0}$ \\
\hline 7 & $\mathbf{0}$ & $\mathbf{0}$ & $\mathbf{1}$ & $\mathbf{1}$ & $\mathbf{1}$ \\
\hline $\mathbf{8}$ & $\mathbf{1}$ & $\mathbf{1}$ & $\mathbf{0}$ & $\mathbf{0}$ & $\mathbf{1}$ \\
\hline $\mathbf{1}$ & $\mathbf{1}$ & $\mathbf{1}$ & $\mathbf{1}$ & $\mathbf{0}$ & $\mathbf{0}$ \\
\hline 10 & $\mathbf{1}$ & $\mathbf{0}$ & $\mathbf{0}$ & $\mathbf{1}$ & $\mathbf{1}$ \\
\hline 11 & $\mathbf{0}$ & $\mathbf{1}$ & $\mathbf{0}$ & $\mathbf{1}$ & $\mathbf{1}$ \\
\hline 12 & $\mathbf{0}$ & $\mathbf{0}$ & $\mathbf{1}$ & $\mathbf{1}$ & $\mathbf{1}$ \\
\hline
\end{tabular}

Sumber : Hasil Penelitian 2019

\section{Analisa Pola Frekuensi Tinggi}

1. Pembentukan 1 Itemset

Proses pembentukan $\mathrm{C} 1$ atau disebut dengan 1 itemset dengan jumlah minimum support $=30 \%$ Dengan rumus sebagai berikut :

$$
\underset{=}{\operatorname{Support}(A)} \frac{\sum \text { Transaksi yang mengandung A }}{\sum \text { Transaksi }} \quad *
$$

Berikut merupakan perhitungan pembentukan 1 itemset :

$S$ (Britama)

$$
=\frac{\Sigma \text { Britama }}{\Sigma 12}=\frac{8}{12} * 100 \%=66,67 \%
$$

S (Britama Rencana)

$$
=\frac{\Sigma \text { Britama Rencana }}{\Sigma 12}=\frac{7}{12} * 100 \%=58,33 \%
$$


$S$ (Britama Junio)

$$
=\frac{\Sigma \text { Britama Junio }}{\Sigma 12}=\frac{7}{12} * 100 \%=58,33 \%
$$

\section{$S$ (Britama Muda)}

$$
=\frac{\Sigma \text { Britama Muda }}{\Sigma 12}=\frac{6}{12} * 100 \%=50 \%
$$

$S$ (Simpedes)

$$
=\frac{\Sigma \text { Simpedes }}{\Sigma 12}=\frac{8}{12} * 100 \%=66,67 \%
$$

Berdasarkan uraian diatas, maka dapat dibuat Tabel 4. :

Tabel 4. Support dari Tiap Itemset

\begin{tabular}{|l|r|r|}
\hline \multicolumn{1}{|c|}{ Itemset } & Jumlah & \multicolumn{1}{c|}{ Support } \\
\hline Britama & 8 & $\mathbf{6 6 , 6 7 \%}$ \\
\hline Britama Rencana & 7 & $\mathbf{5 8 , 3 3 \%}$ \\
\hline Britama Junio & 7 & $\mathbf{5 8 , 3 3 \%}$ \\
\hline Britama Muda & 6 & $\mathbf{5 0 \%}$ \\
\hline Simpedes & 8 & $\mathbf{6 6 , 6 7 \%}$ \\
\hline
\end{tabular}

Sumber : Hasil Penelitian (2018)

2. Kombinasi 2 itemset

Proses pembentukan $\mathrm{C}_{2}$ atau disebut dengan 2 itemset dengan jumlah minimum support $=30 \%$ Dapat diselesaikan dengan rumus sebagai berikut :

Support $(A, B)=P(A \cap B)$

$\operatorname{Support}(A, B)=\frac{\Sigma \text { Transaksi yang mengandung A,B }}{\Sigma \text { Transaksi }} * 100 \%$

Berikut merupakan perhitungan pembentukan C2 atau 2 itemset :

S ( Britama, Britama Rencana)

$$
=\frac{\begin{array}{c}
\Sigma \text { Transaksi Britama dan } \\
\text { Britama Rencana }
\end{array}}{\Sigma 12}=\frac{5}{12} * 100 \%=\begin{gathered}
41,67 \\
\%
\end{gathered}
$$


S ( Britama, Britama Junio )

$$
=\frac{\begin{array}{c}
\Sigma \text { Transaksi Britama dan } \\
\text { Britama Junio }
\end{array}}{\Sigma 12}=\frac{4}{12} * 100 \%=\begin{gathered}
33,33 \\
\%
\end{gathered}
$$

S ( Britama, Britama Muda)

$$
=\frac{\sum \text { Transaksi Britama dan }}{\text { Britama Muda }}=\frac{2}{12} * 100 \%=16,67 \%
$$

S( Britama, Simpedes)

$$
=\frac{\begin{array}{c}
\Sigma \text { Transaksi Britama dan } \\
\text { Simpedes }
\end{array}}{\Sigma 12}=\frac{5}{12} * 100 \%=\begin{gathered}
41,67 \\
\%
\end{gathered}
$$

S ( Britama Rencana, Britama Junio )

$$
=\frac{\begin{array}{c}
\Sigma \text { Transaksi Britama Rencana } \\
\text { dan Britama Junio }
\end{array}}{\Sigma 12}=\frac{3}{12} * 100 \%=\begin{gathered}
25,00 \\
\%
\end{gathered}
$$

S( Britama Rencana, Britama Muda)

$$
=\frac{\begin{array}{c}
\Sigma \text { Transaksi Britama Rencana } \\
\text { dan Britama Muda }
\end{array}}{\Sigma 12}=\frac{3}{12} * 100 \%=25,00 \%
$$

$S$ ( Britama Rencana, Simpedes)

$$
=\frac{\begin{array}{c}
\Sigma \text { Transaksi Britama Rencana } \\
\text { dan Simpedes }
\end{array}}{\Sigma 12}=\frac{3}{12} * 100 \%=25,00 \%
$$

S( Britama Junio, Britama Muda )

$$
=\frac{\sum \text { Transaksi Britama Junio dan }}{\text { Britama Muda }}=\frac{3}{12} * 100 \%=25,00 \%
$$

S ( Britama Junio, Simpedes)

$$
=\frac{\sum \text { Transaksi Britama Junio dan }}{\text { Simpedes }}=\frac{4}{12} * 100 \%=\begin{aligned}
& 33,33 \\
& \%
\end{aligned}
$$

S ( Britama Muda, Simpedes)

$$
=\frac{\sum \text { Transaksi Britama Muda dan }}{\text { Simpedes }}=\frac{4}{12} * 100 \%=\begin{aligned}
& 33,33 \\
& \% 12
\end{aligned}
$$


Berdasarakan uraian diatas, maka dapat dibuat Tabel 5.:

Tabel 5. Calon 2 itemset

\begin{tabular}{|l|c|r|}
\hline \multicolumn{1}{|c|}{ Itemset } & Jumlah & \multicolumn{1}{c|}{ Support } \\
\hline Britama, Britama Rencana & 5 & $\mathbf{4 1 , 6 7 \%}$ \\
\hline Britama, Britama Junio & 4 & $\mathbf{3 3 , 3 3 \%}$ \\
\hline Britama, Britama Muda & 2 & $16,67 \%$ \\
\hline Britama, Simpedes & 5 & $\mathbf{4 1 , 6 7 \%}$ \\
\hline Britama Rencana, Britama Junio & 3 & $25,00 \%$ \\
\hline Britama Rencana, Britama Muda & 3 & $25,00 \%$ \\
\hline Britama Rencana, Simpedes & 3 & $25,00 \%$ \\
\hline Britama Junio, Britama Muda & 3 & $25,00 \%$ \\
\hline Britama Junio, Simpedes & 4 & $\mathbf{3 3 , 3 3 \%}$ \\
\hline Britama Muda, Simpedes & 4 & $\mathbf{3 3 , 3 3 \%}$ \\
\hline
\end{tabular}

Sumber : Hasil penelitian(2018)

3. Kombinasi 3 itemset

Proses pembentukan $\mathrm{C}_{3}$ atau disebut dengan 3 itemset dengan jumlah minimum 30\% Dapat diselesaikan dengan rumus sebagai berikut :

$$
\operatorname{Support}(A, B, \text { dan } C)=\frac{\sum \text { Transaksi yang mengandung }}{\Sigma \text { Transaksi }} * 100 \%
$$

Berikut merupakan perhitungan pembentukan C3 atau 3 itemset :

Suport ( Britama, Britama Rencana, Britama Junio)

$$
=\frac{\begin{array}{c}
\Sigma \text { Transaksi Britama, Britama } \\
\text { Rencana dan Britama Junio }
\end{array}}{\Sigma 12}=\frac{1}{12} * 100 \%=8,33 \%
$$

Suport ( Bitama, Britama Rencana dan Simpedes)

$$
=\frac{\begin{array}{c}
\Sigma \text { Transaksi Britama, Britama } \\
\text { Rencana dan Simpedes } \\
\Sigma 12
\end{array}}{212} * \frac{2}{12} * 100 \%=\begin{aligned}
& 16,66 \\
& \%
\end{aligned}
$$

Suport ( Britama, Britama Rencana dan Britama Muda)

$$
=\frac{\begin{array}{c}
\Sigma \text { Transaksi Britama, Britama } \\
\text { Rencana dan Britama Muda }
\end{array}}{\Sigma 12}=\frac{1}{12} * 100 \%=8,33 \%
$$


Suport ( Britama, Britama Junio dan Simpedes)

$$
=\frac{\begin{array}{c}
\Sigma \text { Transaksi Britama, Britama } \\
\text { Junio dan Simpedes }
\end{array}}{\Sigma 12}=\frac{2}{12} * 100 \%=\begin{aligned}
& 16,66 \\
& \%
\end{aligned}
$$

Suport ( Britama, Simpedes dan Britama Muda)

$$
=\frac{\begin{array}{c}
\Sigma \text { Transaksi Britama, Simpedes } \\
\text { dan Britama Muda }
\end{array}}{\Sigma 12}=\frac{1}{12} * 100 \%=8,33 \%
$$

Suport ( Britama Junio, Simpedes dan Britama Muda)

$$
\begin{aligned}
& \Sigma \text { Transaksi Britama Junio, } \\
& =\frac{\text { Simpedes dan Britama Muda }}{\Sigma 12}=\frac{2}{12} * 100 \%=16,66 \%
\end{aligned}
$$

Berdasarkan uraian diatas, maka dapat dibuat Tabel 6. :

Tabel 6. Kombinasi 3 itemset

\begin{tabular}{|l|r|r|}
\hline \multicolumn{1}{|c|}{ Itemset } & Jumlah & \multicolumn{1}{|c|}{ Support } \\
\hline Britama, Britama Rencana dan Britama Junio & 1 & $\mathbf{8 , 3 3 \%}$ \\
\hline Britama, Britama Rencana dan Simpedes & 2 & $\mathbf{1 6 , 6 7 \%}$ \\
\hline Britama, Britama Rencana dan Britama Muda & 1 & $\mathbf{8 , 3 3 \%}$ \\
\hline Britama, Britama Junio, Simpedes & 2 & $\mathbf{1 6 , 6 7 \%}$ \\
\hline Britama, Simpedes, Britama Muda & 1 & $\mathbf{8 , 3 3 \%}$ \\
\hline Britama Junio, Simpedes, Britama Muda & 2 & $\mathbf{1 6 , 6 7 \%}$ \\
\hline
\end{tabular}

\section{Pembentukan Aturan Asosiasi Final}

Setelah semua pola frekuensi tinggi ditemukan, baru dicari aturan asosiasi yang memenuhi syarat minimum Confidence dengan menghitung Confidence aturan asosiatif $\mathrm{A} \rightarrow \mathrm{B}$. Minimal Confidence $=60 \%$. Nilai Confidence dari aturan $\mathrm{A} \rightarrow \mathrm{B}$ diperoleh dengan rumus sebagai berikut :

$$
=\begin{aligned}
& \text { Confidence }=P(A / B) \\
& \frac{\sum \text { Transaksi yang mengandung A dan }}{\mathrm{B}}
\end{aligned} * 100 \%
$$

Dari kombinasi 2 itemset yang telah ditemukan, dapat dilihat besarnya nilai support, dan confidence dari calon aturan asosiasi seperti lihat tabel 7. 
Table 7. assosiasi final

\begin{tabular}{|l|c|c|}
\hline \multicolumn{1}{|c|}{ Aturan } & \multicolumn{2}{|c|}{ Confidence } \\
\hline $\begin{array}{l}\text { Jika penjualan produk Britama, maka akan penjualan produk } \\
\text { Britama Rencana }\end{array}$ & $5 / 8$ & $62,50 \%$ \\
\hline $\begin{array}{l}\text { Jika Penjualan Produk Britama Rencana, maka akan penjualan } \\
\text { produk Britama }\end{array}$ & $5 / 7$ & $71,42 \%$ \\
\hline $\begin{array}{l}\text { Jika Penjualan Produk Britama, maka akan penjualan produk } \\
\text { Britama Junio }\end{array}$ & $4 / 8$ & $50,00 \%$ \\
\hline $\begin{array}{l}\text { Jika Penjualan Produk Britama Junio, maka akan penjualan } \\
\text { produk Britama }\end{array}$ & $4 / 7$ & $57,14 \%$ \\
\hline $\begin{array}{l}\text { Jika Penjualan Produk Britama, maka akan penjualan produk } \\
\text { Simpedes }\end{array}$ & $5 / 8$ & $62,50 \%$ \\
\hline $\begin{array}{l}\text { Jika Penjualan Produk Simpedes, maka akan penjualan produk } \\
\text { Britama }\end{array}$ & $5 / 8$ & $62,50 \%$ \\
\hline $\begin{array}{l}\text { Jika Penjualan Produk Britama Junio, maka akan penjualan } \\
\text { produk Simpedes }\end{array}$ & $4 / 7$ & $57,14 \%$ \\
\hline $\begin{array}{l}\text { Jika Penjualan Produk Simpedes, maka akan penjualan produk } \\
\text { Britama Junio }\end{array}$ & $4 / 8$ & $50,00 \%$ \\
\hline $\begin{array}{l}\text { Jika Penjualan Produk Britama Muda, maka akan penjualan } \\
\text { produk Simpedes }\end{array}$ & $4 / 6$ & $66,67 \%$ \\
\hline $\begin{array}{l}\text { Jika Penjualan Produk Simpedes, maka akan penjualan produk } \\
\text { Britama Muda }\end{array}$ & $4 / 8$ & $50,00 \%$ \\
\hline
\end{tabular}

\section{Pengolahan Data dengan Tanagra}

Di bawah ini merupakan data-data penjualan produk dana diinput menggunakan Tanagra Versi 1.4 yang hasilnya dapat dilihat pada tabel dan gambar pembuatan Form Tabular pada lembar kerja Ms.Excel sebagai berikut :

Tabel 8. Format tabular

\begin{tabular}{|c|c|c|c|c|c|}
\hline Bulan & Britama & $\begin{array}{c}\text { Britama } \\
\text { Rencana }\end{array}$ & $\begin{array}{c}\text { Britama } \\
\text { Junio }\end{array}$ & $\begin{array}{c}\text { Britama } \\
\text { Muda }\end{array}$ & Simpedes \\
\hline $\mathbf{1}$ & $\mathbf{1}$ & $\mathbf{0}$ & $\mathbf{1}$ & $\mathbf{0}$ & $\mathbf{1}$ \\
\hline $\mathbf{2}$ & $\mathbf{1}$ & $\mathbf{1}$ & $\mathbf{0}$ & $\mathbf{0}$ & $\mathbf{1}$ \\
\hline $\mathbf{3}$ & $\mathbf{0}$ & $\mathbf{1}$ & $\mathbf{1}$ & $\mathbf{1}$ & $\mathbf{0}$ \\
\hline $\mathbf{4}$ & $\mathbf{1}$ & $\mathbf{1}$ & $\mathbf{0}$ & $\mathbf{1}$ & $\mathbf{0}$ \\
\hline $\mathbf{5}$ & $\mathbf{1}$ & $\mathbf{0}$ & $\mathbf{1}$ & $\mathbf{0}$ & $\mathbf{1}$ \\
\hline $\mathbf{6}$ & $\mathbf{1}$ & $\mathbf{1}$ & $\mathbf{1}$ & $\mathbf{0}$ & $\mathbf{0}$ \\
\hline $\mathbf{7}$ & $\mathbf{0}$ & $\mathbf{0}$ & $\mathbf{1}$ & $\mathbf{1}$ & $\mathbf{1}$ \\
\hline $\mathbf{8}$ & $\mathbf{1}$ & $\mathbf{1}$ & $\mathbf{0}$ & $\mathbf{0}$ & $\mathbf{1}$ \\
\hline $\mathbf{9}$ & $\mathbf{1}$ & $\mathbf{1}$ & $\mathbf{1}$ & $\mathbf{0}$ & $\mathbf{0}$ \\
\hline 10 & $\mathbf{1}$ & $\mathbf{0}$ & $\mathbf{0}$ & $\mathbf{1}$ & $\mathbf{1}$ \\
\hline 11 & $\mathbf{0}$ & $\mathbf{1}$ & $\mathbf{0}$ & $\mathbf{1}$ & $\mathbf{1}$ \\
\hline 12 & $\mathbf{0}$ & $\mathbf{0}$ & $\mathbf{1}$ & $\mathbf{1}$ & $\mathbf{1}$ \\
\hline
\end{tabular}




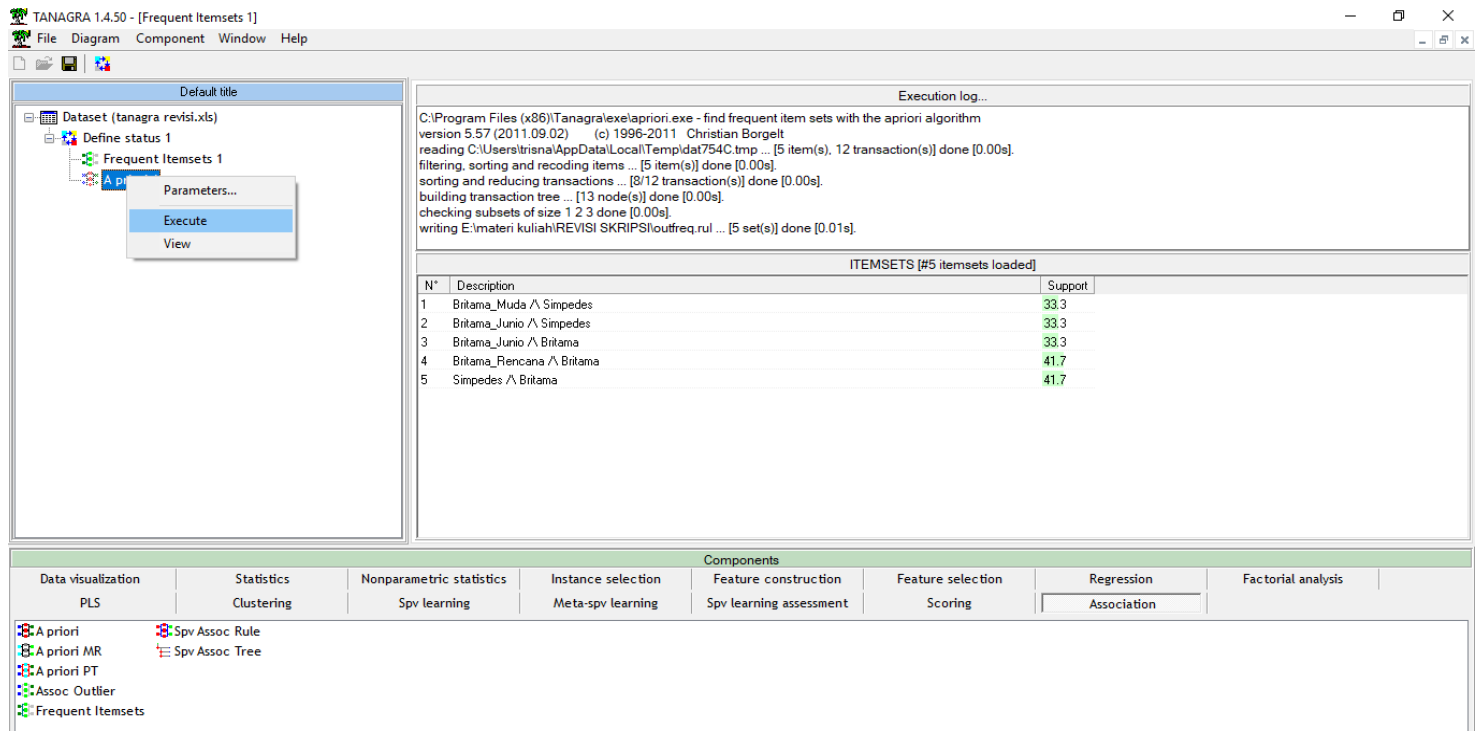

Sumber: Hasil Penelitian (2018)

\section{Gambar 2. Kombinasi 2 item set}

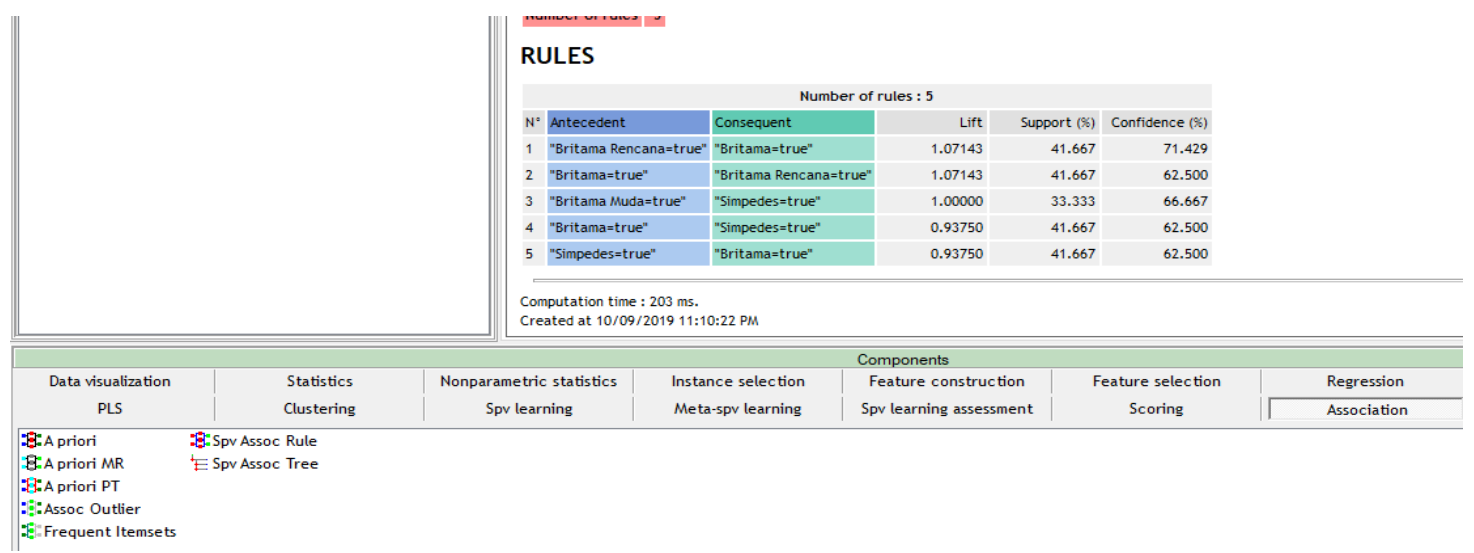

Sumber: Hasil Penelitian (2018)

\section{Gambar 3. Asosiasi Final}

Gambar diatas merupakan hasil output dari data mining pada penjualan produk dana pada PT Bank Rakyat Indonesia (Persero)Tbk Kanca Jakarta Pasar Minggu, maka dapat dibuat aturan (rule) seperti berikut dari output diatas:

1. Britama Rencana, Britama dengan nilai Support 41,67\% dan nilai Confidence $71,42 \%$. Aturan tersebut berarti " $71,42 \%$ dari transaksi di database yang memuat item Britama Rencana juga memuat item Britama, sedangkan 41,67\% dari seluruh transaksi yang ada di database memuat kedua item itu". 
2. Britama, Britama Rencana dengan nilai Support 41,67\% dan nilai Confidence $62,50 \%$. Aturan tersebut berarti “ $62,50 \%$ dari transaksi di database yang memuat item Britama juga memuat item Britama Rencana, sedangkan 41,67\% dari seluruh transaksi yang ada di database memuat kedua item itu".

3. Britama Muda, Simpedes dengan nilai Support 33,33\% dan nilai Confidence $66,67 \%$. Aturan tersebut berarti " $66,67 \%$ dari transaksi di database yang memuat item Britama Muda juga memuat item Simpedes, sedangkan 33,33\% dari seluruh transaksi yang ada di database memuat kedua item itu".

4. Britama, Simpedes dengan nilai Support 41,67\% dan nilai Confidence 62,50\% Aturan tersebut berarti " $62,50 \%$ dari transaksi di database yang memuat item Britama juga memuat item Simpedes, sedangkan 41,67\% dari seluruh transaksi yang ada di database memuat kedua item itu".

5. Simpedes, Britama dengan nilai Support 41,67\% dan nilai Confidence $62,50 \%$ Aturan tersebut berarti " $62.50 \%$ dari transaksi di database yang memuat item Simpedes juga memuat item Britama, sedangkan 41,67\% dari seluruh transaksi yang ada di database memuat kedua item itu".

\section{KESIMPULAN}

Dari hasil pembahasan penelitian tentang Penerapan Data Mining Menggunakan Algoritma Apriori, maka penulis dapat mengambil kesimpulan, sebagai berikut:

1. Setelah melakukan pengujian dengan cara perhitungan manual dan penghitungan menggunakan software Tanagra Versi 1.4, dapat diketahui bahwa hasil yang diperoleh dari perhitungan manual tidak jauh berbeda dengan perhitungan menggunakan software Tanagra Versi 1.4. sehingga secara umum software telah bekerja dengan baik karena proses perhitungan telah sesuai dengan yang diharapkan.

2. Dengan perhitungan algoritma apriori dapat ditemukan hubungan antar tiap produk dana yang diminati nasabah secara bersamaan.

3. Algoritma apriori dapat ditemukan produk dana simpanan yang paling banyak terjual yaitu Britama Rencana dan Britama, dengan menghasilkan kesimpulan bahwa produk dana simpanan Britama Rencana dan Britama dengan nilai Support 
41,67\% dan nilai Confidence 71,42\% atau produk dana simpanan Britama dan Britama Rencana dengan nilai Support 41,67\% dan nilai Confidence 62,50\%.

\section{DAFTAR PUSTAKA}

Assiroj, P. (2018). Penerapan Data Mining Pada Data Transaksi Superstore Untuk Mengetahui Kemungkinan Pelanggan Membeli Product Category Dan Product Container Secara Bersamaan Dengan Teknik Asosiasi $M$... Penerapan Data Mining Pada Data Transaksi Superstore Untuk Mengetahui . 1(March), 11-18. https://doi.org/10.5281/zenodo.1186482

Azis, M. A., Hadianto, N., Miharja, J., \& Rifai, S. (2018). Implementasi Algoritma Apriori Untuk Analisa Pemilihan Tipe Genre Film Anime (Studi Kasus: Myanimelist.Net). Jurnal Pilar Nusa Mandiri, 14(2), 209. https://doi.org/10.33480/pilar.v14i2.932

Bidang, P., Sains, K., Informatika, D. P., Kamus, R., Jepang, B., Indonesia, -, ... Anas, A. (2017). Jurnal Edik Informatika. 2.

Fajrin, A. A., \& Handoko, K. (2018). Penerapan Data Mining Untuk Mengolah Association Rule Tata Letak Buku Dengan Metode.

Halal, M. S. (2018). Analisis perbandingan volume penjualan sebelum dan sesudah mendapatkan sertifikasi halal. 4(2), 267-273.

Penerapan Metode Association Rule Menggunakan Algoritma Apriori Pada Simulasi Prediksi Hujan Wilayah Kota Bandung. (2016). Jurnal Ilmiah Teknologi Informasi Terapan, 2(3).

Purbaningtyas, R., Arizal, A., \& Wardoyo, T. (2017). PENERAPAN ALGORITMA APRIORI TID SEBAGAI METODE OPTIMASI PENCARIAN DATA PADA APLIKASI MOBILE SIDOARJO on HANDS (SoH). Jurnal Penelitian Pos Dan Informatika, $7(2), \quad 87$. https://doi.org/10.17933/jppi.2017.070201

Riyadi, A. A. (2018). Pengolahan Data Awal. Jurnal Pilar Nusa Mandiri, 14(2), 195200.

Sikumbang, E. D. (2018). Penerapan Data Mining Penjualan Sepatu Menggunakan Metode Algoritma Apriori. 4(1), 156-161.

Suntoro, J. (2019). Data Mining Algoritma Dan Implementasi dengan pemograman PHP. Jakarta: PT Elex Media Komputindo.

Wahyuni, S., Suherman, \& Harahap, lumalo portibi. (2017). Implementasi Algoritma. Prosiding SINTAK 2017, 2(2), 31-39. 